INTERNATIONAL JOURNAL OF PLANT PROTECTION VOLUME 10 | ISSUE 2 | OCTOBER, 2017| 256-262
- e ISSN-0976-6855 | Visit us : www.researchjournal.co.in

\title{
Evaluation of various aqua suspension formulations of Metarhizium anisopliae (Metschnikoff) Sorokin
}

\author{
S. D. PATIL ${ }^{1 *}$ AND R. S. JADHAV 2 \\ ${ }^{1}$ Agricultural Research Station, Niphad, NASIK (M.S.) INDIA \\ ${ }^{1}$ Department of Entomology, College of Agriculture, LATUR (M.S.) INDIA
}

\section{ARITCLE INFO}

Received : 09.03 .2017

Revised : 06.08 .2017

Accepted : 20.08.2017

\section{KEY WORDS :}

Metarhizium aniosopliae, Media, Yeast extract, Biomass, Colony forming unit, Spodoptera litura
*Corresponding author: saurushrutu@gmail.com

\begin{abstract}
Studies on evaluation of eleven aqua suspension formulations of entomopathogenic fungus, Metarhizium aniosopliae comprising 1) M.a.+ TW(0.5\%) + CMC (0.5\%) 2) M.a. $+\mathrm{SFO}(1.0 \%)+\mathrm{CMC}(0.5 \%), 3)$ M.a. $+\mathrm{SFO}(1.0 \%)+\mathrm{HO}(1.0 \%) 4)$ M.a. $+\mathrm{GNO}(0.5 \%)+$ $\mathrm{BA}(2.0 \%), 5)$ M.a. $+\mathrm{GNO}(0.5 \%)+\mathrm{CMC}(0.5 \%), 6)$ M.a.+ $\mathrm{GNO}(0.5 \%)+\mathrm{GH}(0.5 \%), 7)$ M.a.+ GH (0.5\%)+HO (1.0\%), 8) Control (M.a.alone) were carried out. At 3 DAI, AS formulation with M.a.+ $\mathrm{GNO}(0.5 \%)+\mathrm{CMC}(0.5 \%)$ registered significantly highest $(88.33 \%)$ surface coverage. The next promising formulations were M.a.+ SFO $(1.0 \%)+$ $\mathrm{CMC}(0.5 \%)(78.33 \%)$, M.a. $\mathrm{GNO}(0.5 \%)+\mathrm{GH}(0.5 \%)(56.67 \%)$ and $M . a .+\mathrm{GH}(0.5 \%)+$ HO $(1.0 \%)(51.67 \%)$. Least $(8.33 \%)$ growth of the fungus was recorded in M.a.+TW $(0.5 \%)+\mathrm{CMC}(0.5 \%)$; when, control recorded 30.0 per cent surface coverage. On 10 DAI, the differences (6.67 to $11.43 \mathrm{~g}$ ) for biomass production were significant. M.a. + SFO $(1.0 \%)+C M C(0.5 \%)$ maintained its superiority over rest of the formulations by producing $11.43 \mathrm{~g}$ biomass. However, it was at par with M.a.+SFO $(1.0 \%)+\mathrm{HO}(1.0)$ $(11.10 \mathrm{~g})$. Maximum cfu count was observed in M.a.+SFO $(1.0 \%)+\mathrm{HO}(1.0 \%)\left(2.33 \times 10^{9}\right)$. However, it was at par with M.a.+SFO $(1.0 \%)+\mathrm{CMC}(0.5 \%)\left(2.27 \times 10^{9}\right)$. The least $(30.0 \%$, $6.67 \mathrm{~g}$ and $17.672 \times 10^{8} \mathrm{cfu} / \mathrm{ml}$ ) surface coverage biomass and cfu count were recorded in control i.e. the formulation (M.a.alone), respectively. In case of bioefficacy of various formulations against larvae of Spodoptera litura, the formulation with M.a.+ SFO $(1.0 \%)+\mathrm{HO}(1.0 \%)$ registered significantly highest mortality of 80.00 and 73.33 per cent of II and III instar larvae of S.litura.
\end{abstract}

How to view point the article : Patil, S.D. and Jadhav, R.S. (2017). Evaluation of various aqua suspension formulations of Metarhizium anisopliae (Metschnikoff) Sorokin. Internat. J. Plant Protec., 10(2) : 256-262, DOI : 10.15740/HAS/IJPP/10.2/256-262. 